\title{
Thoughts and Perspectives on Carlo Michelstaedter
}

\author{
Saila G* \\ Universidad Nacional de General San Martín (UNSAM), Argentina
}

*Corresponding author: Gabriel Saia, Universidad Nacional de General San Martín (UNSAM), Alvear 1334, Villa Ballester, Argentina, Tel: +541130553260; Email: gabriel.saia92@gmail. com

\section{Research Article}

Volume 4 Issue 2

Received Date: April 30, 2021

Published Date: May 25, 2021

DOI: $10.23880 /$ phij-16000179

\section{Abstract}

Carlo Michelstaedter (Gorizia, 1887-1910) left a singular trail in the Italian philosophy of the early 20th century. Almost one hundred and eleven years after his demise, his suicide, one can still discuss the influence of the Italian thinker, the vitality of their topics and the depth of his thought. It is important to know, somehow, the figure that subsists behind the thinker of Persuasion and Rhetoric. For this purpose, a tour of his philosophical work, letters, poetry and dialogues is not enough; it help us to shed light on the fascinating creation of the last nihilism doctor, the last great diagnosis of the deep lack of sense that carried the last part of the 19th century and inaugurated the first decade of the 20th century. Michelstaedter must be defended from merely suicidal readings. Like an elegy, perhaps even an ode, remembering the Italian philosopher in these times remains a fruitful, unfinished and extremely mysterious undertaking.

Keywords: Persuasion; Rhetoric; Nihilism; Pessimism; Suicide; Michelstaedter

Il ne faut pas abandonner le suicide à des gens malheureux qui risquent de le gâcher et d'en faire une misère ${ }^{1}$ "Un plaisir aussi simple", Michel Foucault

Carlo Michelstaedter was born in Gorizia on 3 June 1887. Twenty-three years later, on October 17 th, 1910, housed briefly in his native home, he finds the horizon of his Life, infinity stalks him and decides to respond to the call of a theory that is only theory as action. The search for the Absolute turns on itself, it is tangible, it is experience: "L'assoluto non l'ho mai conosciuto, ma lo conosco così come chi soffre d'insonnia conosce il sonno, come chi guarda l'oscurità conosce la luce"2 (Michesltaedter, 1995, p. 55). But

1 We must not abandon suicide to unhappy people who risk ruining it and making it a misery. Unless otherwise stated, the translation is mine.

2 I did not know the absolute, but I do know it. I know it as one who suffers from insomnia and knows the dream, as one who, by looking into the his youth should not create in us a prejudice, but rather a laughter, an astonishing curiosity and a crackling seriousness. By chance, Michelstaedter belonged to a generation of socalled "precocious suicides", if we may mention this paradox, this oxymoron, made up of two other fleeting geniuses, such as Otto Weininger and George Trakl. The geographical proximity also has to add an element for those who like to make such a comparison, although the landscape described by the triestine in its copious correspondence always refers us to beautiful and familiar places. What is left for us? To trace a chronological path, a sort of biography based on Carlo Michelstaedter's relations? Do a deferred panegyric for a time that exceeds the century of duration? Treat two or three of his key concepts for the history of philosophy, i.e., "rhetoric", "persuasion", "will"? Talk about his exemplary Death? None of these questions are necessary, but neither are they inopportune in this situation to delve into the figure that

darkness, knows the light. 


\section{Philosophy International Journal}

Michelstaedter offers us, beyond his Death, as if in a session of spiritualism - which is what we do in doing academic philosophy - we were looking for a way back to extract what Deleuze intended to expose - and I return to spiritualismwith the "creation of concepts", the first task of philosophy itself. As if it were a game between virtuality and actuality, concepts that are not easily exhausted, that have, in an ontological degree, an incessant exhaustiveness. Everything we can do here and now will correspond, as Michelstaedter reminds us when reading the preface to his doctoral thesis, which is both an accusation and a request of principle, to the domain of rhetoric:

Io lo so che parlo perché parlo ma che non persuaderò nessuno; e questa è disonestà - ma la rettorica anagkázhei me taûta drân bía - o in altre parole $<<$ è pur necessario che se uno ha addentato una perfida sorba la risputi $>>^{3}$ (Michelstaedter, 1995, p. 3).

Even so, as he finally admits it under the tragic aspect: we cannot evade the poison that rhetoric entails, which language implies in its full expression. "Con le parole guerra alle parole"4 (Michelstaedter, 1995, p. 134), thus begins the posthumous writing that is made up of appendices to his great work, his doctoral thesis never defended, La persuasione e la rettorica. This study marked a change in Michelstaedter's life. So let us talk about their origins and relationships, and then move on to a few topics that articulate their opus magnum and finally address the "case" of Michelstaedter.

\section{The Relations}

We can mention anecdotally that he was born into a wealthy Triestine and Hebrew family. His parents were Alberto and Emma, he had two sisters and a brother, Gino, Paula and Elda. As a young man he was introverted and devoted much of his time mainly to poetry, music, sketching. He did not excel in elementary school, as well as at the end of his basic education, having a performance that we could call "unsatisfactory". At the beginning of his academic life, he moved to Vienna to study mathematics, although soon, in October 1905, he moved to Firenze (Michelstaedter, 2010, pp. 26-30) and enrolled in Lettere (Literature) at the Istituto di Studi Superiori. We know little of their relationships, beyond the proper names of girlfriends or "friends", Iolanda De Blasi, Nadia Baraden and Argia Cassini, and some correspondence addressed to them ${ }^{5}$; the same goes for their friends, Enrico Mreule, Nino Paternolli, Gaetano Chiavacci and Vladimiro

3 I know I am talking because I'm talking, but also know I shall not persuade anyone, and this is dishonesty, but the rhetoric forced me to do it, - to put it another way, "if you bite into a crabapple, you must to spit it out.

4 With words, war against words".

5 In addition to a short pseudo-biographical fiction novel written by the curator of his work, Sergio Campailla (2010).
Arangio-Ruiz ${ }^{6}$. That is, we can only recreate relationships to the extent that we have vast epistolary references and some other posthumous evocations ${ }^{7}$. However, and focusing mainly on two crucial moments in his life, we can specify a little more the thick of his bonds. Michelstaedter's friendly, familiar and jovial writing begins to show its dark face at a precise moment, in a letter addressed to his friend Chiavacci on February 26th, 1909, where we can read: "il mio fratello di New York è morto. - Morto per un maledetto accidente, e ora dopo due settimane non sappiamo niente di più. È da impazzire"8 (Michelstaedter, 2010, p. 372). Bearing in mind that the first letters we have from February 1909 are also addressed to Chiavacci, we can imagine that the exchange with his friend corresponds both to the death of his brother and to the production of his thesis, his posthumous work. So we read in a letter sent by Carlo at the beginning of that fateful month: "Per quello spiraglio della rettorica ho contemplato cose tanto più interessanti -amaramente interessanti che ora mi secca maledettamente limitarmi a quella meschinità - ma: omnia in omni!!... et omnia nihil"9 (Michelstaedter, 2010, p. 370). But this idea was foreshadowed in the young man before, around May of the previous year, when he told his father that, on the occasion of a work of school philology, he was only interested in the relationship between "eloquence" and "rhetoric" in Brunetto Latini's translation of the speech Pro Q. Ligario Oratio of the great Cicero (La Rocca, 2011).

Undoubtedly, the genesis of the text is chaotic, not least with its writing, and if we follow the chronological division that Chiavacci makes of Carlo's work in the introduction of Opere (1958), we can find that the years 1908-1909 would correspond to a kind of "assolutto pessimismo" ("absolute pessimism") which culminates in 1910, when thought ceases to be theory and becomes "immanent criterion to action, life in action" (Michelstaedter, 1958, p. xiv). Several epistles bear witness to this, such as the one addressed to Enrico Mreule on June 13th, 1909, where he expounds at length his theory

6 The latter also officiated as their editors on the occasion of the first publication of La persuasione e la rettorica (1913; Genova: Formigini, a cura di V. Arangio-Ruiz) and of the main compilation of their writings in Opere (1958; Firenze: Sansoni, a cura da Chiavacci). We can add to these two editions that made by his cousin, Emilio Michelstaedter (1922; Firenze: Vallecchi, a cura da Emilio Michelstaedter), and one last by Maria Raschini (1972). Thus, we have four posthumous editions of La persuasione e la rettorica, until, in the 70-80's, Sergio Campailla made the critical edition of the "complete" of his poetic, philosophical, pictorial and epistolary work. To subvert these, and closer to the edition of Chiavacci and the Manoscritto "C", the critical edition of Andrea Comincini, edited by Joker in 2015.

7 As is the case with the notes left by Emilio, the preface to Opere (1958), or the first biography of the gorizian thinker written by Campailla (1974).

8 My brother in New York is dead. He died in a cursed accident, and now, after two weeks, we don't know anything else. It's crazy.

9 Through the slit of rhetoric I contemplated things so interesting, bitterly interesting, that now it irritates me to dedicate myself only to that meanness, although: everything is in everything!... and everything is nothing. 


\section{Philosophy International Journal}

of the gymné psykhé ("naked soul"), or the one destined for Chiavacci, of April 25th, 1910, where fatigue leads him to label a drawing of his room with a legend in Greek: "têde dè egò mèn bíon ábion diabióo érgon dè méga phyei" ${ }^{\prime 10}$ (Michelstaedter, 2010 , p. 463, note 2). It would be enough to give a literary "low blow" and read again the last letter that Carlo wrote to his mother, dated September 10th, 1910, where the quality of the writing shows what Chiavacci mentions in step: the theory becomes act, it ceases to see (and to be show) and begins to be. Just as it is taken for granted that we read of our own free will, perhaps even out of pleasure, but as a violent act, we hear music with hardly any intention and inevitably. That is, the passage from the theoreîn to the real philosophía, that is, the one that wants not for itself ${ }^{11}$ or its breadth of field, but for its action, for its good. Likewise, Carlo's relations are marked by this marked tendency towards a productive desire. In this way, and to conclude with the intermingling of Carlo's relations, we come to a perhaps more conflicting point: persuasion and rhetoric.

\section{The Person and the Thought}

Somehow, we are already beginning to diagram the main structure of the work: vacillations around everything that we can call "inauthentic", "fictitious", "social", faced with what we say "authentic", "individual" and, in short, "philosophia perennis". Michelstaedter expresses a fervent spirit that stands against the Modern and, let me generalize here, the Germans; neither futurist nor dannunziano, much less Hegelian. Nor should we be surprised that he is not nietzschean at all. Nietzsche is still very positive to understand the value behind his finding, behind his critique of German historicism, as he primarily does in Vom Nutzen und Nachteil der Historie für das Leben (the second untimely) as well as during the beginning of his life as an author, and remaining his entire life and oeuvre ${ }^{12}$. There is no method in Carlo Michelstaedter, and that is simply reprehensible, but there is certainly a struggle, a search, a purpose. It does not recognize itself as modern and that is why it does not treat its own time with "justice"; it does not recognize part of the Austro-Hungarian empire, it does not respect its German roots; it does not recognize rhetoric, it tries to assume the weight and ownership of persuasion. If we turn to his

10 Here, where I live a life that cannot be lived, a great work sprouts.

11 Michelstaedter is clear about this: there are philologists, philosophers, lovers of knowing the good hierarchical structures, who become lovers of polylogy, become, in the manner of Heraclitus, polymathas. Cfr. Michelstaedter, 1958, p. 717.

12 As in the "first" Nietzsche, Carlo presents an interest in pedagogy (compare with the lectures Über die Zukunft unserer Bildungsanstalten) and, clearly, in classical philology, which will then give way to purely philosophical reflections (as in the text of the German author Die Geburt der Tragödie). This text does not focus on comparing both authors, due to its length, but this is a work that still remains vacant. writings, not only to his letters, but mainly to La persuasione $e$ la rettorica we will find a pastiche game, a palimpsest that combines several languages and sources not only in its materiality (Italian, Greek, Latin, German), but also in its style (direct, formal, alliterated, interrupted, with German em dashes) and interests (philosophy, poetry, tragedy, mathematics, chemistry, the workers life, the bourgeoisie). It resists writing ${ }^{13}$, makes it murky and almost ominous, but it is because persuasion requires that in order to not be rhetorical ${ }^{14}$. Michelstaedter makes us think of the character that today is Kafka: a Czech Jew - by extension, AustroHungarian - who wrote in German at the beginning of the last century. But the melting pot becomes even richer in Carlo (Benvegnù, 2016), where the experience of minor writing is given at every step. Not only because he published nothing but four small newspaper articles during his lifetime (one without his express consent), but also because he faces a double distance: he does not want to be a scholar, he does not want to be a common man. We must note, too, that his own native Gorizia is a mosaic of rich and stormy Mitteleuropa cultures $^{15}$.

In effect, Michelstaedter's struggle turns towards two well-separated bands. "Rhetoric" means everything that allows us to stay alive; society, the homeland, order, laws, but also work, philosophy as a search to increase knowledge, the church with its rituals, science and its reified subjects. With this term we can understand everything that is improper, impersonal, obtuse, that is always done with a view to a future and that has a past as a very well present; in short, everything that will never be an end itself. It is what turns language into a trap, since in its main purpose (communicate=convince) it violence its conditions of possibility: it is recreated in deceptive formulas that seek a petty objective ${ }^{16}$.

13 And also to the reading, as we are reminded by the anecdote that Campailla gathers in the introduction of its critical edition of La persuasione e la rettorica regarding the impressions of the very first editor of the text: I could not get a precise idea of the value and novelty of what was said in the text. I found a serious defect, which we must strive to eliminate as much as possible: the poor dead man (sc. Michelstaedter) did not write in Italian, and it is necessary to translate into the correct language what he expressed as he could, as he knew how to speak our language (Michelstaedter, 1995, pp. ix-x).

14 In the manner of Catch-22 by Joseph Heller: only through language can the uselessness of it be verified. The pilot asks for a psychiatric check-up for his discharge, but by filling out the form, he's already corroborating his (cap) ability. The only thing left to the pilot is the act, outside the form, and that act either consummates the "Catch" or immolates it, phagocytes it and makes it implode. Analogous to Catch-22, unfathomable at first glance, philopsykhia functions as an irrepressible "love of life", i.e., "cowardice".

15 For a detailed study, cfr. Ara A, Magris C (1982) Trieste. Una identità di frontiera. Torino: Einaudi. Although this view that Magris presents is very biased, since on several occasions we can note that Carlo was first and foremost Italian, and his Germanophile interest is only exhibited on a few occasions.

16 And for this very reason, dishonest: Michelstaedter, 1958, p. 770. 


\section{Philosophy International Journal}

The persuaded mode evades this question, because it does not even remain in its field (the rhetorical field) but operates according to another logic, that of the present, that of the conscious and own being. The man persuaded has to establish a situation where his communication, instead of conviction, looks for something different: it is the message of Jesus, of Buddha - which they never wrote-, but also that of Ibsen: do not imitate to be a disciple, the good disciple is dedicated to following. And that is why after the aforementioned quotation from the Preface ("Io lo so che parlo...") of his thesis, he adds: "Eppure quanto io dico è stato detto tante volte e con tale forza che pare impossibile che il mondo abbia ancor continuato ogni volta dopo che erano suonate quelle parole"17 (Michelstaedter, 1995, p. 3). And of course, it refers to Jesus and Buddha, as I said, who succumb in their message in front of the theological building, but also to the classical Greeks, i.e., Parmenides, Heraclitus, Empedocles, who formed a catalogue of "naturists" (physikoi) for Aristotle, let alone Socrates or Beethoven, who were interpreted, sliced and digested (systematically in both cases, either according to philosophical "tradition" or counterpoint).

Thus, the persuaded has, as a figure who draws limits, a moral conscience that is his own, abandoning the axiological plexuses so expensive for society, for civilization. Before knowing and thinking were one and the same, Carlo tells us. There was no big closet where to place mummified ideas. It is for this very reason that philosophy is conceived as the last of the bastions of rhetoric: Plato and Aristotle were its principal architects ${ }^{18}$. It is worth mentioning that the initial title of his doctoral thesis was I concetti da persuasione e rettorica in Platone ed Aristotele ${ }^{19}$, purported doxographic work, which later became an ontological, psychological, social and linguistic treatise. Michelstaedter's thought does not leave aside the role of philology, at all, less if one reviews the Appendici Critiche ("Critical Appendices"), where he collects and comments on passages from Platonic and Aristotelian works, but if he extends his work to an impossible thesis, a company he recognizes as such.

To round it off, two different and antagonistic modes are those that articulate the vital possibility: persuasion and rhetoric. The thesis aimed to problematize this second pole

17 However, what I say was said so many times and with such force that it seems impossible that the world has continued as if nothing every time these words were uttered.

18 While Michelstaedter has great appreciation and even admiration for the first (sc. Plato), he rejects the second (sc. Aristotle):

Attachment to life generates the probability of salvation - and coexistence generates society - but those who live together are preserved -in the balance of evil. - Because in life everything happens in relation to everything - in fact, life is an accident. This is my science, and Aristoteles is miserable (Michelstaedter, 2010, p. 384).

19 The concepts of persuasion and rhetoric in Plato and Aristotle. initially, but then it moved towards the place that corresponds to it, that is, the uomo persuaso ("persuaded man"). What kind of work would a true philosopher have presented, according to the terms Michelstaedter understands? It is not worth asking ourselves about a work that was not, because there are plenty of possible readings, however obsidian and dark these are.

\section{Towards a Brief Century}

Something worth discussing is "why Michelstaedter?". Set out in the corpus composed of La persuasione e la rettorica, the notes by Appendici Critiche, the schooling of the Scritti Vari ("Chosen writings") and the notions he gives us glimpses of in Dialogo della salute ("Dialogue of Health"), we can see very strong theses about the beginnings of a tumultuous and brief Century. Carlo did not see the war, did not live it, did not participate in it; his mother, sister and other relatives, yes, in their own flesh. Carlo knew nothing about fascism, except for the ideas of D'Annunzio, an author he probably read or heard about. Mussolini was a few years older than Carlo, in 1910 he had little political relevance, and he harbored more animus of prisoner and nietzschean -obviously in a D'Annunzian way- than of Duce. In other words, Carlo lived only in the decadence of the late nineteenth century. In short, unless for personal dilemmas (Nadia B., her brother, the departure of a dear friend for Argentina), we can risk thinking that Carlo lived his life. Michelstaedter studied, thought, wrote tirelessly, made friends and maintained loves, but did not have the motivations of the later generation, or of those who saw more number of days. We can find, however, profuse ideas that raise faces such as that of Heidegger, Wittgenstein, Jaspers, Lukács. Our author foreshadows, as if he were a prophet, the most crucial problems of the first half of the century: the linguistic turn, scientific-moral relativism, the relation of the subaltern, hermeneutics, phenomenology, finitude, fallen modes, the being-in-the-world, the being-fordeath. Of course, it is not a visionary or a superior intellectual, nor would he want it that way, but rather a philósophos, a persuaded one, a formal limit in the rhetorical structure, a break, a between. In several ways, Carlo was not a victim of his time, but a doctor who evaluates the symptoms, which operates above the determinations of logocentrism and the problems carried by the phoné (of course, time before even the birth of Jacques Derrida). But what woke up after his death?

There is a good article written by Sergio Campailla (2018), "Las primeras interpretaciones de Michelstaedter (1910-1916)" "'The first interpretations of Michelstaedter (1910-1916)"), where this gives us a very clear reading line. Carlo had no editorial purpose as such, he did not know how to be a precocious essayist, in the manner of Slataper, nor 


\section{Philosophy International Journal}

a young professor like Nietzsche ${ }^{20}$, but those who collected his works for the post suicidium publication generated a stir around the figure of the young philosopher. The death by his own hand of a 20-year-old in Trieste already generated rumors and fervent appropriations, and in his brief writing Campailla manages to give an account of how Papini, Cecchi and Borgese were the first to adduce "metaphysical" causes. The young Papini even had access to the text of the Gorizian doctoral student, which was not edited until two years after the latter's death, and it is possible that he made a translation based on the death of Otto Weininger. For their part, motivated by the novelty of the publication of Michelstaedter's first volume of poetry, the Triestinians Slataper and Benco do their part. In this case suicide takes on a different aspect: work is everything, the truth is everything. It is worth, in his judgment, committing suicide for the sake of work, for the sake of truth. More unusual thing is that the countrymen of Michelstaedter appeal again to the Papinian source, to the one who did not even read the work and equally ventured a theory. But these weren't the only ones to talk. After Cecchi and Borgese - which we decided to omit because of the monotony of their hypotheses-, Amendola sees the passage from theorein to aggire (act), from the saying (seen) to the fact (heard) as a sufficient motive (Campailla, 2018).

But that is not all, since it is enough to look back a bit at our days to discover a revealing article in this sense: "Sobre el suicidio lógico" ("On logical suicide") by Miguel Morey (2014). Here we rehearse a return to the concepts of "metaphysical" and "logical" as adjectives of the suicidal act. Inspired by the challenge of Albert Camus, Morey invites us to review a little the paths that Michelstaedter traveled in his last years of life, between 1908 and 1910, time of writing of his infinite Tesi di laurea. He reminds us that his friend Enrico, who was at the genesis of his doctoral project, gave him the revolver that would end his days before leaving for Argentina, going into the sea, going into the desert ${ }^{21}$. Morey points out something concrete: Carlo, as we said, did not experience the horrors of war, nor fascism, nor communism, nor Auschwitz (Morey, 2014); he did not see the birth of the Reich and the familiar-cathexis. But that is not what is important; the important thing is that he knew these selfish and petty phenomena, clearly rhetorical. Thus, his friend Enrico Mreule has to wander through a world that Carlo had glimpsed thanks to Parmenides, Plato, Schopenhauer and Buddha: the good disciple is that who follows.

20 He came to feel real contempt for this last profession which he calls "vain".

21 This perspective is revived and narrated by Magris in his novel (1991), where he gathers the supposed experience of Enrico Mreule and his Patagonian journey.

\section{One Last Word}

To risk drawing a hypothesis is far-fetched, petty, cowardly, rhetorical. However, it would also be a good idea to miss the opportunity to add some final notes on the Michelstaedter case and, above all, on the phenomenon of suicide. It should be clarified that this is not done for the sake of those who can no longer feel the look on themselves, but for us, knowing that we are not dead we can still look. Look. Again, theorein that tries to dodge prejudice; while observing, it shows. A good word to describe this last act is "mystery", a biological and psychological impossibility to establish a reliable cause. When we talk about suicide, we tend to address extreme moods, either reductionist or emergent, because there is no way to think about suicide in a simple way, other than as an epiphenomenon. Michelstaedter's suicide remains in the anecdote, as this does not produce any kind of archive or memory. Let us try with a clear and concise definition: suicidal is the one who cannot tell us his experience, the one of which there is no trace or trace, the solitary acolyte. Maybe the Life is that pursued by Michelstaedter. Be that as it may, and to match him with the thinker we made use of at the beginning of this little work, Gilles Deleuze, maybe he didn't take his own life. It is possible that neither the Frenchman nor the Gorizian thought of Life denial when they launched the final act. Perhaps our introspection will tell us this: to try to know what happened, how it happened, why it happened is to recreate once again the rhetoric, the game of references that we sister (and enemy) as a society. But the rhetorical machine always assumes a certain violence, whether political, descriptive, evaluative or "philosophical". To remove the absolute from the environment, or not to make of one's own will a mere will-for, will-over-means, will of absolute. At first we talked about the concepts, those "ontologics" that get tired, that are exhaustive, that we exhaust, and perhaps it does make sense to return to this endearing character, despite the temporal, local and physical distance, to live with him. Whether life deserves to be lived or not, great dilemma; however, and away from the schopenhauerean Quietiv ("barbituric") of music, let us say that for this time it does not matter. I write this in a context of pandemic, quarantine, uncertainty: there is no better time to link up with the past and the future. Revisionism and opinions everywhere come together and articulate our daily lives, waiting, perhaps, for mythical resolutions. Myth about myth, as is rhetoric, let us not get carried away by messianism and resort to the doubly utopian idea of Michelstaedter: we must renounce the nonplace, as well as the Aristotelian rhetoric of the topoi. I apologize for this fleeting inclusion and without excuse, but we are, in short, a weight that falls or a hot-air ballon that floats; that falls because it falls, that floats because it floats. It doesn't matter. What needs to be overcome in both cases is gravity. 


\section{References}

1. Ara A, Magris C (1982) Trieste. Una identità di frontiera. Einaudi.

2. Benvegnù D (2016) Toward a Minor Michelstaedter. en Italian Culture 34(2): 81-97.

3. Campailla S (2018) Las primeras interpretaciones de Michelstaedter (1910-1916). Zibaldone, Estudios Italianos 6(1): 51-62.

4. Campailla S (2010) Il segreto di Nadia B. Marsilio, pp: 248.

5. Campailla S (1974) A ferri corti con la vita. Comune di Gorizia, pp: 141.
6. Foucault M (1979) Un plaisir si simple. Le Gai Pied.

7. La Rocca C (2011) La persuasione (e l'oratoria). en Humanitas 66: 811-835.

8. Magris (2012) Un altro mare. Milano: Il sole 24 ore.

9. Michelstaedter C (2010) Epistolario. A cura di Sergio Campailla. Adelphi, pp: 18-489.

10. Michelstaedter C (1995) La persuasione e la retorica. Adelphi, pp: 18-387.

11. Michelstaedter C (1958) Opere. Firenze: Sansoni.

12. Morey M (2014) Sobre el suicidio lógico. en Scientia Helmantica 2(3): 56-70. 